
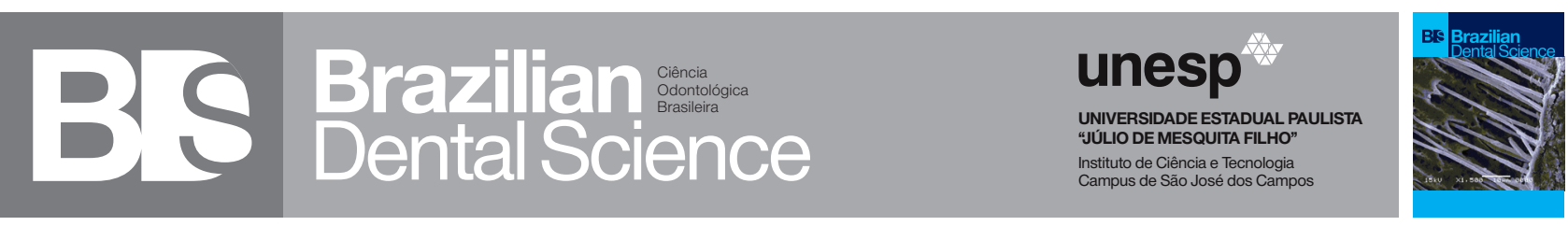

\title{
Prevalence of melanin pigmentation in a yemeni population and its relation to some risk factors
}

\author{
Prevalência de pigmentação da melanina em uma população iemenita e sua relação com fatores de risco \\ Wadhah Abdulnasser ALHAJJ ${ }^{1,2}$, Mohammed Nasser ALHAJJ ${ }^{3}$ \\ 1 - Department of Periodontology - Faculty of Dentistry - Thamar University - Dhamar - Yemen. \\ 2 - Department of Biological and Preventive Sciences - Faculty of Dentistry - University of science and technology - Sana'a - Yemen. \\ 3 - Department of Prosthodontics - Faculty of Dentistry - Thamar University - Dhamar - Yemen.
}

\section{ABSTRACT}

Objective: The present study aimed to explore the prevalence of melanin pigmentation in a sample of Yemeni population and its relation to some possible risk factors. Material and Methods: This crosssectional study was performed on 440 patients attending a private clinic. Printed questionnaires were introduced to the patients and a clinical examination was performed for each patient. The questionnaire included questions regarding demographic data, and questions regarding some common habits such as smoking, khat chewing and consuming of hot drinks. Melanin pigmentation was assessed regarding its presence, most affected areas and the numbers of affected quadrants. The data were managed and analyzed using SPSS software program. Descriptive statistics and inferential statistics were performed and the associations of melanin with risk factors were evaluated at $P$ value $<0.05$. Results: Four hundred and forty patients with mean age $29 \pm 8.21$ years were included in the study. Of them, $67.5 \%$ were fair-skinned, $26.8 \%$ were smokers, $48.2 \%$ were khat chewers and $33.6 \%$ were hot drinks consumers. The prevalence of melanin pigmentation was $62.7 \%$, with class I represented $56.5 \%$ of cases. Males showed more prevalence $(67.9 \%)$ of melanin pigmentation than females $(57.7 \%)$ with no significant difference. Results also showed more prevalence of melanin pigmentation in patients $>25$ years, and darkskinned patients. Regarding habits, smoking, khat chewing and hot drink consumption habits showed significant associations with melanin pigmentation. Whereas the association of khat chewing and hot drinks alone with melanin pigmentation showed no significant relationship with melanin pigmentation while, the merge effects of khat chewing and smoking habits together with melanin pigmentation showed

\section{RESUIMO}

Objetivo: O presente estudo teve como objetivo explorar a prevalência de pigmentação da melanina em uma amostra da população iemenita e sua relação com alguns possíveis fatores de risco. Material e Métodos: Trata-se de um estudo transversal com 440 pacientes atendidos em uma clínica particular. Cada paciente respondeu a um questionário impresso e passou por um exame clínico. O questionário incluía perguntas sobre dados demográficos e questões sobre alguns hábitos comuns, como fumar, mastigar khat e consumir bebidas quentes. A pigmentação da melanina foi avaliada quanto à presença, áreas mais afetadas e número de quadrantes afetados. Os dados foram gerenciados e analisados no programa SPSS. Foi realizada estatística descritiva e inferencial e as associações de melanina com fatores de risco foram avaliadas com valor de $\mathrm{p}<0,05$. Resultados: Quatrocentos e quarenta pacientes com idade média de $29 \pm 8,21$ anos foram incluídos no estudo. Desses, $67,5 \%$ eram de pele clara, $26,8 \%$ eram fumantes, $48,2 \%$ eram usuários de khat e 33,6\% eram consumidores de bebidas quentes. A prevalência de pigmentação da melanina foi de $62,7 \%$, com a classe I representando $56,5 \%$ dos casos. Os homens apresentaram maior prevalência $(67,9 \%)$ de pigmentação por melanina do que as mulheres $(57,7 \%)$, sem diferença significativa. Os resultados também mostraram maior prevalência de pigmentação da melanina em pacientes > 25 anos e pacientes de pele escura. Quanto aos hábitos, tabagismo, mascar khat e consumo de bebida quente apresentaram associação significativa com a pigmentação da melanina. Enquanto a associação de mascar khat e bebidas quentes isoladamente não mostrou relação significativa com a pigmentação de melanina, enquanto os efeitos da associação dos hábitos de mascar e fumar khat juntamente com pigmentação por melanina mostraram relação significativa com a pigmentação 
significant relationship with melanin pigmentation. Conclusion: It can be concluded that Yemeni people had high prevalence of melanin pigmentation with more prevalence of CL I type. Males, patients > 25 years and dark-skinned patients showed more prevalence of melanin pigmentation. Smoking, khat chewing and hot drinks consuming habits had significant associations with melanin pigmentation.

\section{KEYWORDS}

Melanin; Yemeni; Smoking; Khat chewing; Risk. por melanina. Conclusão: Pode-se concluir que o povo iemenita apresentou alta prevalência de pigmentação por melanina, com maior prevalência do tipo CL I. Homens, pacientes $>25$ anos e pacientes de pele escura apresentaram maior prevalência de pigmentação da melanina. O hábito de fumar, mascar khat e consumir bebidas quentes teve associações significativas com a pigmentação da melanina.

\section{PALAVRAS-CHAVE}

Melanina; Iemenita; Tabagismo; Mascar Khat; Risco.

\section{INTRODUCTION}

$\mathrm{T}$ he harmony of smile is determined not only by the shape, the position and the color of the teeth but also by the gingival tissue. Gingival health and appearance are essential components for an attractive smile, and removal of unsightly pigmented gingiva is the need for a pleasant and confident smile [1]. Normal physiologic color of gingiva is coral or salmon pink, with physiological variations that depend upon the degree of vascularization, epithelial thickness, the thickness of keratinized layer and the amount of melanin pigment [2]. Melanin, a brown pigment, is the most common natural pigment contributing to endogenous pigmentation of the gingiva. It is a non-hemoglobin-derived pigment formed by cells called melanocytes that are dendritic cells of neuroectodermal origin in the basal and spinous layers [1]. Oral pigmentation occurs in all races of man. There are no significant differences in oral pigmentation between males and females. The intensity and distribution of racial pigmentation of the oral mucosa is variable, not only between races but also between different individuals of the same race and within different areas of the same mouth $[3,4]$. The variation in color is due to amount, distribution and depth of melanin. Blue discoloration represents melanin deposits in the connective tissue whereas brown discoloration is associated with superficial deposition in the epithelium [5]. Attached gingiva is the most commonly effected intraoral site [6]. Gingival pigmentation often occurred in the labial area of anterior teeth. Excessive pigmentation in palatal mucosa as a result of tobacco smoke is a rare phenomenon, except in instances of reverse smoking.

Melanin pigmentation is probably genetically determined, but, as suggested by
Dummett, in 1945 [2] the degree of pigmentation is partially related to mechanical, chemical and physical stimulation. Melanin pigmentation in gingiva is correlated with active smoking: smokers displayed a greater propensity toward pigmentation than did nonsmokers. [3] Intake of antimalarial drugs including chloroquine and quinidine [7] is also associated with oral pigmentation. In darker skinned people, oral pigmentation increases but there is no difference in the number of melanocytes between fairskinned and dark-skinned individuals. The variation is related to differences in the activity of melanocytes [1]. Melanin pigmentation in human gingiva has been reported in several countries. To best of our knowledge, there is no published article about the prevalence of melanin pigmentation in Yemen. So, the present study was aimed to determine the prevalence of melanin (racial) pigmentation in a sample of Yemeni population and its relation with some suspected risk factors.

\section{METHODOLOGY}

A software program (G*Power v. 3.0.10, Los Angeles, CA, USA) was used to calculate the sample size. The power was set to be $90 \%$ using $P$ value of 0.05 . This revealed that 440 patients were needed for the study. Informed consents were obtained from all patients and printed questionnaire was introduced to each patient accompanied with clinical examination. The questionnaire included questions regarding demographic data (age and sex), questions regarding habits such as: smoking (prevalence and duration), khat chewing (prevalence, frequency, and duration), and consuming of hot drinks. Skin color was also evaluated through 
visual assessment as the visual assessment remains one of the "gold standard" methods of assessing skin color. [8]

\section{Evaluation of melanin pigmentation}

Melanin pigmentation was assessed in the oral cavity. Brownish or black pigmentation in gingiva was classified according to extent of pigmentation unit in the labial aspect of anterior teeth (Figure 1). The clinical assessment of melanin pigmentation included its presence, most affected area and the numbers of affected quadrants. The method for the evaluation of the gingival pigmentation was followed according to modification of melanin index categories [3]. Upper right quadrant was coded as "1", upper left "2", lower left " 3 " and lower right "4" (Table I). Exclusion criteria included: a) Gingival pigmentation of hemoglobin, melanoid, melanoma and carotene [9], b) Gingival pigmentation adjacent to amalgam restoration, and c) Long-term usage of antimalarial drugs [7] and minocycline [10].
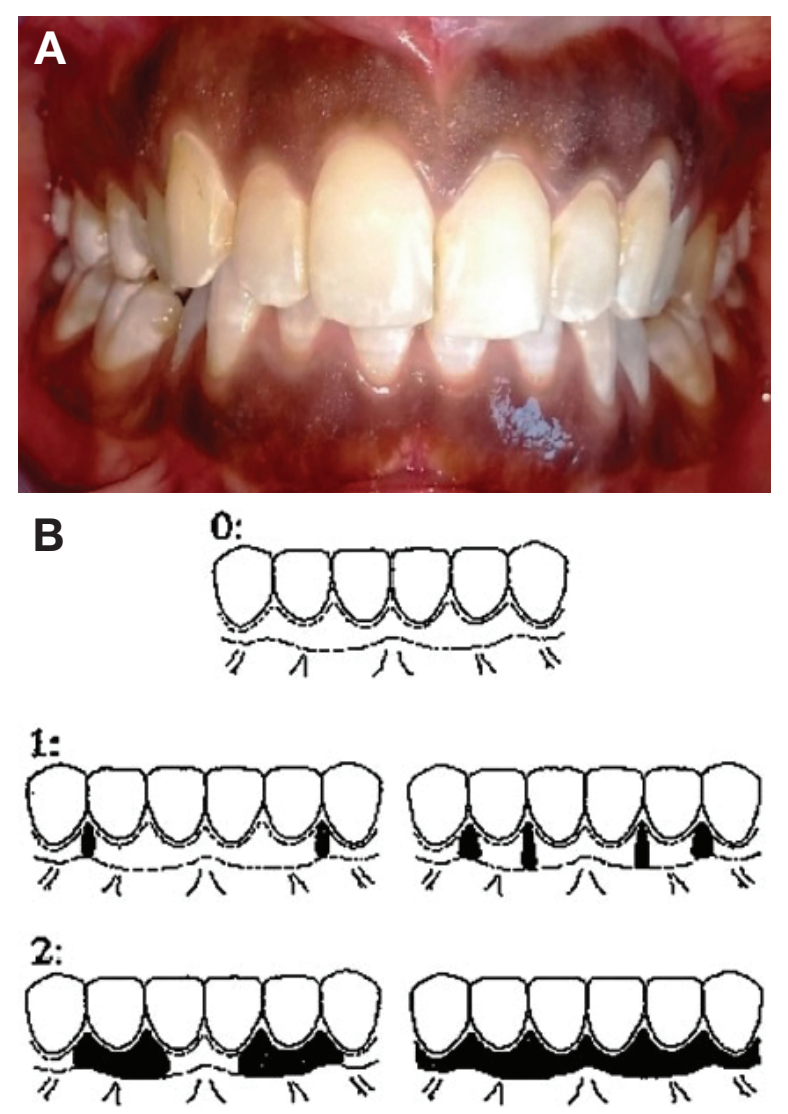

Figure 1 - a) Classification according to extent of brownish or black pigmentation in labial gingiva of anterior teeth. B) Cl II melanin pigmentation
The data were managed and analyzed using SPSS software program for Windows. Descriptive statistics and inferential statistics were performed. Descriptive statistics were performed in terms of means, frequencies, and percentages for study variables. The association of melanin with risk factors were then evaluated. For comparison between both genders, age groups, khat chewing groups, smoking groups, and hot drinks consuming groups, non-parametric Mann-Whitney and Kruskal-Willis tests were used as appropriate. $\mathrm{P}$ value $<0.05$ was set as significant for all tests. The Odds ratios were also calculated to find out the risk ratios for melanin pigmentation.

\section{RESULTS}

A total of 440 patients (225 " $51.1 \%$ " males and 215 "48.9\%" females) aged from 13 to 50 years with mean age $29 \pm 8.21$ years were included in the study. Of them, $297(67.5 \%)$ were fair-skinned, 118 patients $(26.8 \%)$ were smokers, $212(48.2 \%)$ were khat chewers and 148 patients $(33.6 \%)$ were hot drinks consumers. The prevalence of melanin pigmentation in the study population was found in $62.7 \%$ of the sample. Patients with class I pigmentation represented $56.5 \%$ and the four quadrants were affected in $40.6 \%$ of cases. More details are shown in Table II.

Males showed more prevalence $(67.9 \%)$ of melanin pigmentation than females $(57.7 \%)$ with no significant difference $(\mathrm{OR}=1.5 ; \mathrm{P}=$ 0.313). Also no significant differences were found regarding type of melanin pigmentation and number of affected quadrants between males and females. Results also showed more prevalence of melanin pigmentation in patients older than 25 years compared to patients $\leq 25$ years with significant difference $(\mathrm{OR}=2.7$; $\mathrm{P}=0.018)$. However, class I pigmentation was more prevalent in patients $\leq 25$ years. Dark-skinned patients were 3 times higher to had melanin pigmentation $(79.7 \%)$ than fair-skinned patients (54.5\%) with significant difference $(\mathrm{OR}=3.3 ; \mathrm{P}=0.013)$. Class II was also associated with dark-skinned patients but with no significant difference (Table III).

Results showed that smoking habit had significant association with melanin 
pigmentation $(\mathrm{OR}=3.7 ; \mathrm{P}=0.012)$. Smokers also had more class II pigmentation while nonsmokers had more class I pigmentation with significant difference $(\mathrm{P}=0.017)$. Smokers also had more affected quadrant than non-smokers but with no significant difference $(\mathrm{P}=0.195)$. Duration of the smoking also had significant effect on oral melanin pigmentation. Smokers for more than 5 years had $98.6 \%$ prevalence of pigmentation with a significant difference than smokers less than 5 years. Also, longtime smokers had more prevalence of class II pigmentation (Table IV).

Khat chewing also showed significant association with melanin pigmentation, with more prevalence in khat chewers $(\mathrm{OR}=4.1$; $\mathrm{P}$ $=0.001)$. However, no significant difference in association with class I and II pigmentation or number of the affected quadrants $(P>0.05)$. Regarding frequency of khat chewing, there was no significant difference between daily or not-daily chewing, although the prevalence of melanin pigmentation was 2 times higher in khat chewers $(\mathrm{OR}=2.0 ; \mathrm{P}=0.230)$. Duration of the khat chewing also had no significant effect on oral melanin pigmentation with more prevalence in long-time chewing $(\mathrm{OR}=$ 2.0; $\mathrm{P}=0.405$ ) (Table V).

The effects of khat chewing alone with the exclusion of smoking and hot drink consumption showed that khat chewing only had no significant relationship with melanin pigmentation. Also, the effects of hot drinks consumption alone with the exclusion of smoking and khat chewing showed no significant relationship with melanin pigmentation although the hot drinks consumers had 1.8 times higher of melanin pigmentation. However, the effects of smoking and khat chewing with the exclusion of hot drink consumption showed significant relationship with melanin pigmentation (Table VI).

Results also showed that hot drinks consuming habit had significant association with melanin pigmentation $(\mathrm{OR}=2.9 ; \mathrm{P}$ $=0.022$ ). However, hot drinks consumers didn't show significant difference regarding pigmentation types and number of affected quadrants $(\mathrm{P}>0.05)$ (Table VII).
Table I - Melanin index categories

\begin{tabular}{|c|c|}
\hline Grade & Texture \\
\hline 0 & No pigmentation \\
\hline 1 & $\begin{array}{l}\text { Solitary unit(s) of pigmentation in papillary gingiva without formation of } \\
\text { continuous ribbon between solitary units }\end{array}$ \\
\hline 2 & $\begin{array}{l}\text { At least 1 unit of formation of continuous ribbon extending from } 2 \\
\text { neighboring solitary units }\end{array}$ \\
\hline
\end{tabular}

Table II - Characteristics of the Study

\begin{tabular}{|c|c|c|c|}
\hline & Parameters & $\mathbf{N}$ & $\%$ \\
\hline \multirow{2}{*}{ Gender } & Male & 225 & 51.1 \\
\hline & Female & 215 & 48.9 \\
\hline \multirow{2}{*}{ Skin Color } & Fair & 297 & 67.5 \\
\hline & Dark & 143 & 32.5 \\
\hline \multirow{2}{*}{ Smoking } & Yes & 118 & 26.8 \\
\hline & No & 322 & 73.2 \\
\hline \multirow{2}{*}{$\begin{array}{l}\text { Smoking } \\
\text { duration }\end{array}$} & $<5$ years & 46 & 40.0 \\
\hline & $\geq 5$ years & 72 & 60.0 \\
\hline \multirow{2}{*}{ Khat chewing } & Yes & 212 & 48.2 \\
\hline & No & 228 & 51.8 \\
\hline \multirow{2}{*}{$\begin{array}{l}\text { Khat chewing } \\
\text { frequency }\end{array}$} & Non daily & 117 & 55.2 \\
\hline & Daily & 95 & 44.8 \\
\hline \multirow{2}{*}{$\begin{array}{l}\text { Khat chewing } \\
\text { duration }\end{array}$} & $<5$ years & 57 & 26.9 \\
\hline & $\geq 5$ years & 155 & 73.1 \\
\hline \multirow{2}{*}{$\begin{array}{l}\text { Hot drinks } \\
\text { consuming }\end{array}$} & Yes & 148 & 33.6 \\
\hline & No & 292 & 66.4 \\
\hline \multirow{2}{*}{$\begin{array}{c}\text { Melanin } \\
\text { pigmentation }\end{array}$} & Yes & 276 & 62.7 \\
\hline & No & 164 & 37.3 \\
\hline \multirow{2}{*}{ Classification } & Class I & 156 & 56.5 \\
\hline & Class II & 120 & 43.5 \\
\hline \multirow{4}{*}{$\begin{array}{l}\text { No of affected } \\
\text { quadrants }\end{array}$} & One quadrant & 43 & 15.6 \\
\hline & Two quadrants & 61 & 22.1 \\
\hline & Three quadrants & 60 & 21.7 \\
\hline & Four quadrants & 112 & 40.6 \\
\hline \multirow{4}{*}{$\begin{array}{l}\text { Most affected } \\
\text { quadrants }\end{array}$} & 1st quadrant & 198 & 27.3 \\
\hline & 2nd quadrant & 202 & 27.9 \\
\hline & 3rd quadrant & 163 & 22.5 \\
\hline & 4th quadrant & 161 & 22.3 \\
\hline
\end{tabular}


Table III - Associations of sex, age, and skin color with melanin pigmentation

\begin{tabular}{|c|c|c|c|c|c|c|c|c|c|}
\hline \multirow{2}{*}{$\begin{array}{l}\text { Associated } \\
\text { factors }\end{array}$} & \multicolumn{3}{|c|}{ Sex } & \multicolumn{3}{|c|}{ Age } & \multicolumn{3}{|c|}{ Skin color } \\
\hline & Male & Female & $P$ & $\leq 25$ & $>25$ & $P$ & Fair & Dark & $P$ \\
\hline \multicolumn{10}{|c|}{ Melanin pigmentation } \\
\hline Yes & $152(67.9)$ & $124(57.7)$ & \multirow{2}{*}{0.313} & $86(48.9)$ & $190(72.0)$ & \multirow{2}{*}{$0.018^{*}$} & $162(54.5)$ & $114(79.7)$ & \multirow{2}{*}{$0.013^{*}$} \\
\hline No & $73(32.1)$ & $91(42.3)$ & & $90(51.1)$ & $74(28.0)$ & & $135(45.5)$ & $29(20.3)$ & \\
\hline \multicolumn{10}{|l|}{ Classification } \\
\hline Class I & $77(50.7)$ & $79(63.7)$ & \multirow{2}{*}{0.270} & $66(76.7)$ & $90(47.4)$ & \multirow{2}{*}{$0.049^{\star}$} & $104(64.2)$ & $52(45.6)$ & \multirow{2}{*}{0.142} \\
\hline Class $\|$ & $75(49.3)$ & $45(36.3)$ & & $20(23.3)$ & $100(52.6)$ & & $58(35.8)$ & $62(54.4)$ & \\
\hline \multicolumn{10}{|c|}{ No of affected quadrants } \\
\hline 1 quadrant & $24(15.8)$ & $19(15.3)$ & \multirow{4}{*}{0.776} & $13(18.6)$ & $30(16.9)$ & \multirow{4}{*}{0.794} & $32(19.8)$ & $11(9.70)$ & \multirow{4}{*}{0.442} \\
\hline 2 quadrants & $28(18.4)$ & $33(26.6)$ & & $16(16.3)$ & $45(22.9)$ & & $32(19.7)$ & $29(25.4)$ & \\
\hline 3 quadrants & $43(28.3)$ & $17(13.7)$ & & $15(17.4)$ & $45(23.4)$ & & $28(17.3)$ & $32(28.1)$ & \\
\hline 4 quadrants & $57(37.5)$ & $55(44.4)$ & & $42(47.7)$ & $70(36.8)$ & & $70(43.2)$ & $42(36.8)$ & \\
\hline
\end{tabular}

Table IV - Associations between smoking, and smoking duration with melanin pigmentation

\begin{tabular}{|c|c|c|c|c|c|c|}
\hline \multirow{2}{*}{ Associated factors } & \multicolumn{3}{|c|}{ Smoking } & \multicolumn{3}{|c|}{ Smoking duration } \\
\hline & Yes & No & $P$ & $<5$ yrs & $\geq 5 \mathrm{yrs}$ & $P$ \\
\hline \multicolumn{7}{|l|}{ Melanin pigmentation } \\
\hline Yes & $95(80.5)$ & $181(55.2)$ & \multirow{2}{*}{$0.012^{*}$} & $24(52.2)$ & $71(98.6)$ & \multirow{2}{*}{$0.002^{*}$} \\
\hline No & $23(19.5)$ & $141(44.8)$ & & $22(47.8)$ & $1(1.40)$ & \\
\hline \multicolumn{7}{|l|}{ Classification } \\
\hline Class I & $33(34.7)$ & $123(68.0)$ & \multirow{2}{*}{$0.017^{*}$} & $19(79.2)$ & $14(19.7)$ & \multirow{2}{*}{$0.027^{\star}$} \\
\hline Class II & $62(65.3)$ & $58(32.0)$ & & $5(20.8)$ & $57(80.3)$ & \\
\hline \multicolumn{7}{|l|}{ No of affected quadrants } \\
\hline 1 quadrant & $15(15.8)$ & $28(15.5)$ & \multirow{4}{*}{0.195} & $12(50.0)$ & $4(5.60)$ & \multirow{4}{*}{$0.047^{\star}$} \\
\hline 2 quadrants & $7(7.40)$ & $54(29.8)$ & & $3(12.5)$ & $4(5.60)$ & \\
\hline 3 quadrants & $20(21.0)$ & $40(22.1)$ & & $1(4.20)$ & $19(26.8)$ & \\
\hline 4 quadrants & $53(55.8)$ & $59(32.6)$ & & $8(33.3)$ & $44(62.0)$ & \\
\hline
\end{tabular}

Table V - Associations between khat chewing, and Khat chewing frequency \& duration with melanin pigmentation

\begin{tabular}{|c|c|c|c|c|c|c|c|c|c|}
\hline \multirow{2}{*}{$\begin{array}{l}\text { Associated } \\
\text { factors }\end{array}$} & \multicolumn{3}{|c|}{ Khat chewing } & \multicolumn{3}{|c|}{ Khat chewing frequency } & \multicolumn{3}{|c|}{ khat chewing duration } \\
\hline & Yes & No & $P$ & Non-Daily & Daily & $P$ & $<5$ yrs & $\geq 5$ yrs & $P$ \\
\hline \multicolumn{10}{|c|}{ Melanin pigmentation } \\
\hline Yes & $166(78.3)$ & $110(47.8)$ & \multirow{2}{*}{$0.001^{\star}$} & 85 & $190(72.0)$ & \multirow{2}{*}{0.230} & $39(68.4)$ & 126 (83.2) & \multirow{2}{*}{0.405} \\
\hline No & $46(21.7)$ & $118(52.2)$ & & $32(27.4)$ & $15(15.8)$ & & $18(31.6)$ & $29(16.8)$ & \\
\hline \multicolumn{10}{|l|}{ Classification } \\
\hline Class I & $85(50.9)$ & $71(64.5)$ & \multirow{2}{*}{0.328} & $52(61.2)$ & $36(45.0)$ & \multirow{2}{*}{0.367} & $22(56.4)$ & $61(48.4)$ & \multirow{2}{*}{0.585} \\
\hline Class II & $81(49.1)$ & $39(35.5)$ & & $33(38.8)$ & $44(55.0)$ & & $17(43.6)$ & $65(51.6)$ & \\
\hline \multicolumn{10}{|c|}{ No of affected quadrants } \\
\hline 1 quadrant & $24(14.4)$ & $19(17.3)$ & \multirow{4}{*}{0.635} & $20(23.5)$ & $13(16.3)$ & \multirow{4}{*}{0.77} & $11(28.2)$ & $20(15.9)$ & \multirow{4}{*}{0.694} \\
\hline 2 quadrants & $35(21.1)$ & $26(23.6)$ & & $20(23.5)$ & $12(15.0)$ & & $4(10.3)$ & $27(21.4)$ & \\
\hline 3 quadrants & $40(24.1)$ & $20(18.2)$ & & $19(22.4)$ & $19(23.7)$ & & $9(23.0)$ & $31(24.6)$ & \\
\hline 4 quadrants & $67(40.4)$ & $45(40.9)$ & & $26(30.6)$ & $36(45.0)$ & & $15(38.5)$ & $48(38.1)$ & \\
\hline
\end{tabular}


Table VI - Associations between khat chewing only, and Khat chewing \& smoking only with melanin pigmentation

\begin{tabular}{|c|c|c|c|c|c|c|}
\hline \multirow{2}{*}{ Associated factors } & \multicolumn{3}{|c|}{ Khat chewing only } & \multicolumn{3}{|c|}{ Smoking \& Khat chewing only } \\
\hline & Yes & No & $P$ & Yes & No & $P$ \\
\hline \multicolumn{7}{|l|}{ Melanin pigmentation } \\
\hline Yes & $43(56.6)$ & $81(48.2)$ & \multirow{2}{*}{0.461} & $87(94.6)$ & $99(49.5)$ & \multirow{2}{*}{$<0.001^{\star}$} \\
\hline No & $33(43.4)$ & $87(51.8)$ & & $5(5.40)$ & $101(50.5)$ & \\
\hline \multicolumn{7}{|l|}{ Classification } \\
\hline ClassI & $35(81.4)$ & $50(61.7)$ & \multirow{2}{*}{0.256} & $27(31.0)$ & $61(61.5)$ & \multirow{2}{*}{$<0.001^{*}$} \\
\hline Class II & $8(18.6)$ & $31(38.3)$ & & $60(69.0)$ & $38(38.5)$ & \\
\hline \multicolumn{7}{|l|}{ No of affected quadrants } \\
\hline 1 quadrant & $12(27.9)$ & $17(21.0)$ & \multirow{4}{*}{0.959} & $17(19.5)$ & $14(14.1)$ & \multirow{4}{*}{0.115} \\
\hline 2 quadrants & $11(25.6)$ & $23(28.4)$ & & $4(4.60)$ & $23(23.2)$ & \\
\hline 3 quadrants & $9(20.9)$ & $16(19.7)$ & & $23(26.5)$ & $20(20.2)$ & \\
\hline 4 quadrants & $11(25.6)$ & $25(30.9)$ & & $43(49.4)$ & $42(42.4)$ & \\
\hline
\end{tabular}

Table VII - Associations between hot drinks, and hot drinks only with melanin pigmentation

\begin{tabular}{|c|c|c|c|c|c|c|}
\hline \multirow{2}{*}{ Associated factors } & \multicolumn{3}{|c|}{ Hot drinks } & \multicolumn{3}{|c|}{ Hot drinks only } \\
\hline & Yes & No & $P$ & Yes & No & $P$ \\
\hline \multicolumn{7}{|l|}{ Melanin pigmentation } \\
\hline Yes & $112(75.7)$ & $164(56.2)$ & \multirow{2}{*}{$0.022^{\star}$} & $19(59.4)$ & $84(50.0)$ & \multirow{2}{*}{0.445} \\
\hline No & $36(24.3)$ & $128(43.8)$ & & $13(40.6)$ & $84(50.0)$ & \\
\hline \multicolumn{7}{|l|}{ Classification } \\
\hline Class I & $57(50.9)$ & $99(60.4)$ & \multirow{2}{*}{0.309} & $12(63.2)$ & $52(61.9)$ & \multirow{2}{*}{0.939} \\
\hline Class II & $55(49.1)$ & $65(39.6)$ & & $7(36.8)$ & $32(38.1)$ & \\
\hline \multicolumn{7}{|l|}{ No of affected quadrants } \\
\hline 1 quadrant & $11(9.8)$ & $32(19.5)$ & \multirow{4}{*}{0.404} & $1(5.30)$ & $15(17.9)$ & \multirow{4}{*}{0.232} \\
\hline 2 quadrants & $21(18.8)$ & $40(24.4)$ & & $0(0.0)$ & $24(28.6)$ & \\
\hline 3 quadrants & $20(17.8)$ & $40(24.4)$ & & $4(21.0)$ & $17(20.2)$ & \\
\hline 4 quadrants & $60(53.6)$ & $52(31.7)$ & & $14(73.7)$ & $28(33.3)$ & \\
\hline
\end{tabular}

\section{DISCUSSION}

The intensity and distribution of racial pigmentation of the oral mucosa is variable, not only between races but also between different individuals of the same race and within different areas of the same mouth $[3,4]$. Brownish or black pigmentation in human gingiva has been reported in several countries. To the best of our knowledge, no published studies discussing this topic in Yemen are available. In this study, the prevalence of melanin pigmentation in Yemeni population was $62.7 \%$. Patients with class I represented $56.5 \%$ and class II represented $43.5 \%$. These results contradict another study carried out in Sweden where melanin pigmentation was $9.9 \%$ and reached in smokers to $18.5 \%$. We thought that this contradiction is axiomatical because Swedish is Scandinavian Nordic nations. Other studies showed that melanin pigmentation in the dark-skinned African population was $100 \%$ and in Asians was between $30 \%$ and $98 \%$. [11] We suppose that the high percentage in Yemeni population might due to various habits practiced in the country which may be predisposing factors to melanin pigmentation. Regarding the number of the affected quadrants, results showed that the four quadrants were affected in $40.6 \%$ of cases. Furthermore, we tried to evaluate a possible relationship between any risk factor and most affected quadrant. Our results showed approximately equal distribution of melanin between all quadrants without any 
obvious relationship between risk factors and melanin distribution. To the best of our knowledge, no studies were found to evaluate these parameters. So that, comparison with the literature is limited. In earlier Swedish studies, smoker's melanosis was more frequent among women than men when smoking comparable amounts of cigarettes. This difference was credited to the female sex hormones, which are known to prime the melanocytes to melanin production. [12] In this study, males showed more prevalence $(67.9 \%)$ of melanin pigmentation than females $(57.7 \%)$ with no significant difference. This can be explained by the fact that men have more tendency to smoking and khat chewing than females in Yemeni society. It is worthy to mention that our results are consistent to with the study of Hedin CA and Axell T [13].

Epidemiological studies showed that the percentage of pigmented individuals is higher in adults than in juveniles. [14] It could be speculated upon the oral mucosa is exposed to more melanocyte stimulating factors such as benzopyrene and nicotine. [15] These results are consistent with the results of the present study in which people $>25$ years old had more melanin pigmentation with more CL II pigmentation than patients $\leq 25$ years old. This age is considered as the mean age of adulthood. The relationship of skin color with melanin pigmentation was also evaluated in this study where dark-skinned patients showed higher melanin pigmentation $(79.7 \%)$ than fair-skinned patients (54.5\%). Dark-skinned people had more CL II melanin pigmentation while fair-skinned people had more CL I pigmentation. These results are consistent with that of Dummett CO. [16] who showed that the distribution of oral pigmentation in black individuals was $60 \%$ in the gingiva.

Melanin pigmentation is probably genetically determined, but as suggested by Dummett in 1945 [2] the degree of pigmentation is partially related to mechanical, chemical and physical stimulation. The results of this study showed that the prevalence of melanin pigmentation was $(55.2 \%)$ in nonsmokers and $(80.5 \%)$ in smokers with more CL II pigmentation in smokers. These results are consistenet with Suraj Multani's study [17] in India, who reported melanin pigmentation in $73.4 \%$ non-smokers and $100 \%$ in smokers, and the study of Haresaku et al. who reported $87 \%$ of melanin pigmentation in smokers [18]. However, our results are not convergent with other studies where it was found that the prevalence of melanin pigmentation was 15\% to $37 \%$ for non- smokers among Japanese workers [19]. On the other hand, prevalence was higher in Asian populations (34.6\%) in comparison with Ashkenazi (0.8\%) and Sephardic (11.1\%) Jews. These differences may be due to ethnic differences and presence of different habits in each nation. In a Turkish study, the frequencies of melanin pigmentation were significantly higher in current smokers than in those without any smoking habits which is consistent with results of our study [20].

As noticed from our results, duration of the smoking also had significant association on oral melanin pigmentation. Smokers for more than 5 years had more prevalence of pigmentation with a significant difference than smokers less than 5 years. This results may be logical because of the length of smoking period the gingiva is exposed to more irritations. Regarding khat chewing habit, the percentage of khat chewers in Yemen population was $48.2 \%$ which in accordance to another study done in Kingdom of Saudi Arabia [21]. It was shown that melanin pigmentation was associated with $78.3 \%$ of khat chewers. This is also in agreement with other studies that attributed melanin discoloration to the chemical components of khat [22-24]. Duration of the khat chewing also had no obvious relationship with oral melanin pigmentation. Khat chewers for more or less than 5 years had approximate melanin pigmentation with no significant difference. Based on our knowledge, no documented studies in the literature discussing this topic. 
We supposed that hot drinks may have thermal irritative effect to melanocytes resulting in increase of melanin pigmentation in the mouth. Our results showed that hot drinks consuming habit had an association with melanin pigmentation. In Yemeni community, tobacco smoking, khat chewing and hot drink intake are habitual to be consumed concomitantly. So, the presence of melanin pigmentation may be due the cumulative effects of these factors. Thus, we evaluated the effects of khat chewing and hot drinks alone in absence of other risk factors. The results showed that there were not relationships between khat chewing and hot drinks when consuming lonely with melanin pigmentation which emphasis our suggestion. Finally, because most Yemeni people accustomed to abuse khat and tobacco together, we evaluated the merged effect of both habits which showed strong relationship between smoking and khat chewing together with melanin pigmentation. So, it is recommended that furthers studies should be carried out to assess the lonely effects of khat chewing and hot drinks consumption with larger study samples with exclusion of other suspected risk factors.

\section{CONCLUSION}

Within the limitations of this study, it can be concluded that:

1 - Yemeni people had high prevalence of melanin pigmentation with more prevalence of class I pigmentation;

2 - Males showed more prevalence of melanin pigmentation than females but with no significant difference;

3 - Patients older than 25 years and darkskinned patients showed more prevalence of melanin pigmentation than their counterparts with significant differences;

4 - Smoking, khat chewing and hot drinks consuming habits had significant associations with melanin pigmentation.

\section{REFERENCES}

1. Grover HS, Dadlani H, Bhardwaj A, Yadav A, Lal S. Evaluation of patientresponse and recurrence of pigmentation following gingival depigmentation usinglaser and scalpel technique: a clinical study. J Indian Soc Periodontol. 2014Sep;18(5):586-92. doi:10.4103/0972-124X.142450.

2. Dummett sr CO Clinical observations on pigment variations in healthy oral tissues of the Negro.J Dental Res 1945; 24(1):7-13. doi: https://doi.org/10.1177/ 00220345450240010701

3. Hedin CA. Smokers' melanosis. Occurrence and localization in the attached gingiva. Arch Dermatol. 1977 Nov; 113(11):1533-8.

4. Hedin Ca, Pindborg JJ, Daftary DK, MehtaFS. Melanin depigmentation of the palatal mucosa in reverse smokers: a preliminary study. J Oral Pathol Med. 1992 Nov;21(10):440-4.

5. DummettCO,Barens G. Pigmentation of the oral tissues: a review of the literature.J Jeriodontol. 1967 Sep-0ct;38(5):369-78.

6. Aoki A, Sasaki KM, Watanabe H, Ishikawal. Lasers in nonsurgical periodontal therapy. Periodontol 2000.2004;36:59-97.

7. Birek C, Main JH. Two cases of oral pigmentation associated with quinidine therapy. Oral Surg Oral Med Oral Pathol. 1988 Jul;66(1):59-61.

8. Taylor S, Westerhof W, Im S, Lim J. Noninvasive techniques for the evaluation of skin color.J Am Acad Dermatol. 2006 May;54(5 Suppl 2):S282-90.

9. Ciçek Y,Ertaş U. The normal and pathological pigmentation of oral mucous membrane: a review. J Contemp Dent Pract. 2003 Aug 15;4(3):76-86.

10. Cale AE, Freedman PD, Lumerman H. Pigmentation of the jawbones and teeth secondary to minocycline hydrochloride therapy.J Periodontol. 1988 Feb;59(2):112-4

11. Nagarajappa AK, Pandya D. Adverse drug effects in mouth. Int J Med Appl Sci. 2015;4(1):82-91

12. Axéll T,Hedin CA. Epidemiologic study of excessive oral melanin pigmentation with special reference to the influence of tobacco habits. Scand J Dent Res. 1982 Dec;90(6):434-42

13. Hedin CA, Axéll T. Oral melanin pigmentation in 467 Thai and Malaysian people with special emphasis on smoker's melanosis. J Oral Pathol Med. 1991 Jan:20(1):8-12

14. Brown T.Oral pigmentation in the aborigines of Kalumburu, north-west Australia. Archives of oral biology 1964;9:555-IN512. Brown T. oral pigmentation in the aborigines of Kalumburu, North-West Australia. Arch Oral Biol. 1964 Sep-0ct;9:555-64.

15. Hedin CA, Larsson A. In vitro activation of amphibian dermal melanocytes by nicotine. Scand J DentRes. 1986 Feb;94(1):57-65.

16. DummettCO. Physiologic pigmentation of the oral and cutaneous tissues in the Negro. JDentRes. 1946 Dec;25(6):421-32.

17. Multani S. Interrelationship of smoking, lip and gingival melanin pigmentation, and periodontal status. Addict Health. 2013 Winter-Spring;5(1-2):57-65.

18. Haresaku S, Hanioka T, Tsutsui A, Watanabe T. Association of lip pigmentation with smoking and gingival melanin pigmentation. Oral Dis. 2007 Jan;13(1):71-6.

19. Hanioka T, Tanaka M, Tamagawa H, shizukuishi S. Epidemiologic study of melanin pigmentation in the attached gingiva in relation to cigarette smoking. JDental Health 1993; 43(1): 40-7.

20. Unsal E, Paksoy C, Soykan E, Elhan AH, Sahin M. Oral melanin pigmentation related to smoking in a Turkish population. Community Dent Oral Epidemiol. 2001 Aug;29(4):272-7. 
21. Awadalla NJ,A Suwaydi HA. Prevalence, determinants and impacts of khat chewing among professional drivers in Southwestern Saudi Arabia. East Mediterr Health J. 2017 May 1;23(3):189-97

22. Lukandu OM, Koech LS, Kiarie PN. Oral lesions induced by chronic khat use consist essentially of thickened hyperkeratinized epithelium. Int JDent 2015;2015:104812. doi: 10.1155/2015/104812.
23. Al-Alimi KR, Razak AAA, Saub R Salivary caries parameters: comparative study among Yemeni khat chewers and nonchewers. J Dental Sci. 2014; 9(4): 328-31. doi:https://doi.org/10.1016/j.jds.2014.04.003

24. Al-Kholani Al. Influence of khat chewing on periodontal tissues and oral hygiene status among Yemenis. Dent Res J (Isfahan). 2010 Winter;7(1):1-6.

Wadhah Abdulnasser Alhajj

(Corresponding address)

Department of Periodontology, Faculty of Dentistry, Thamar Univer-

sity, Dhamar, Yemen

Date submitted: 2019 0ct 11

E-mail: waddah.alhaj@gmail.com

Accept submission: 2020 Jan 07 